\title{
COLLABORATIVE STORY WRITING FOR INTERCULTURAL COMMUNICATIVE COMPETENCE DEVELOPMENT
}

\author{
UDC 371.3:811.111'243 \\ 316.72
}

\author{
Nina Lazarević \\ University of Niš, Faculty of Philosophy, Niš, Serbia
}

\begin{abstract}
Development of intercultural communicative competence (ICC) in the constraints of the classroom faces many obstacles: not just formal, in terms of the choice of approaches, material and assessment, but also ethical and value-related. Building intercultural awareness in future teachers is equally important, as they should be prepared not only for the intercultural classroom, but for the imminent diversity that any classroom encompasses: ethnic, socioeconomic, gender, learner style. One of many techniques that have been used in the ICC classroom is cooperative story writing. The collaborative project was done by the American and Serbian university students, the former starting the stories and working under the instruction of Professor Kenneth Cushner, an intercultural communication specialist, and the latter finishing them. The jointly written stories showed that both students were up to a degree stereotypical in their understanding of the other culture, but were at the same aware of the steps that had to be taken to improve intercultural communication. A small-scale study is used to show how the learners' understanding of culture may be enhanced, with a special focus on how future English language teachers might benefit from it.
\end{abstract}

Key words: intercultural communicative competence, pre-service EFL teacher education, story writing, collaborative projects, awareness-raising strategies

\section{INTRODUCTION}

Intercultural communicative competence (ICC) has been consistently more present in education, not only in the curricula of foreign languages but also in the outcomes of the programs in both elementary and high schools (Council of Europe, 2001). It is seen as appropriate knowledge, skills, and attitudes in intercultural situations (Byram, 1997), and more concretely, awareness of differences and similarities and the ability to mediate between different cultures (Byram, 1997). In our local context, ICC has only recently

Submitted July $4^{\text {th }} 2017$, accepted for publication December $13^{\text {th }}, 2017$

Corresponding author: Nina Lazarević

Faculty of Philosophy, Ćirija i Metodija 2, 18000 Niš, Serbia

E-mail: nina.lazarevic@ gmail.com 
been stated in the objectives and outcomes of different subjects, one of them being the English language.

The aims for ICC development in English language learning are stated as 'the development of cognitive abilities, humanistic, moral and aesthetic views, gaining a positive relation to other languages and cultures, as well as to one's own language and heritage, appreciation of differences and being accustomed to openness in communication' (Curriculum for elementary and high school education). This educational aim includes all three domains of ICC: cognitive, affective and behavioural, therefore placing a lot of responsibility on a teacher to achieve them, since no particular material or training is offered to teachers.

Respect for other cultures and values, openness and curiosity are prerequisites that lead to cultural awareness, empathy and understanding of other cultures (Byram, 1997). However, we are not to forget that true understanding cannot be of a language or a culture, but of people who embody them, who act in a particular context. It is, therefore, essential to provide authentic experience for learners. In view of the lack of study abroad opportunities and actual contacts with a particular culture, collaborative projects, of which collaborative story writing is an instance, might be quite an effective tool for awareness-raising and development of intercultural skills.

The education of foreign language teachers should prepare them firstly to understand the complexities of today's world, and equip them with not only intercultural knowledge, but sensitivity and skills. Secondly, with such competences, teachers will be more effective in instilling those same skills, knowledge, and capabilities in their learners. For this to happen, a paradigmatic shift in thinking must occur (Cushner, 2011, Hammer, Bennett, Wiseman 2003), where students will be willing to reconsider their attitudes, explore other cultures and re-evaluate their own. However, research shows that future teachers "may not have the requisite disposition to be effective intercultural educators' nor possess the skills necessary to guide young people to develop intercultural competence" (Cushner, 2011: 604). It is, therefore, of critical importance to involve future teachers into intercultural projects so that they have a firsthand experience in applying knowledge, perfecting their skills and developing positive attitudes towards other culture, so that they, in turn, may become more successful educators.

\section{THEORETICAL UNDERPINNINGS}

\subsection{Culture teaching}

It has been recognized that the range of skills language learners should develop cannot be confined to communicative and linguistic only, but should incorporate a wide range of cooperative and intercultural ones (Byram 1997, Council of Europe 2001, Gutiérrez, 2000). In order to better understand and appropriately react to cultural elements, learners need to develop a new set of skills, those that have been recognized as important for the $21^{\text {st }}$ century, such as global awareness and social and cross-cultural skills (Trilling \& Fadel, 2009). Expecting that due to the intercultural context which is always in the background of language learning (Kramsch, 1993, 2003) learners would naturally develop these competencies and skills has been shown not to give positive results (Byram, 2009; Byram \& Risager, 1999; Deardorff, 2012). If cultural elements are not actively discussed and analyzed, intercultural competence in learners will not 'happen', or follow from linguistics proficiency. 
Another important point in culture teaching is the awareness of the existence of many 'cultures' within one, so as not to represent cultures as monolithic wholes, without variety. Additionally, such an approach might remain on the surface level of culture, and deal only with the objective dimensions (Triandis, 2002), with the visible objects of culture, such as works of art, holidays, or food. What makes the attainment of intercultural competence so difficult is the 'unseen' culture, that subjective dimension with invisible aspects - such as values, norms, attitudes, worldviews (Cushner, 1992). It is here that intercultural problems occur due to the unawareness of the fact that the unseen elements dictate behaviour of people and their interpretation of events.

There are many approaches to be taken when preparing students for the international arena, from study-abroad programs, over different simulation games (e.g. Barnga, $\mathrm{BaFaBaFa}$ ) to particular techniques (e.g. cultoons, critical incidents, culture capsules) to be realized in the classroom. One of the techniques that indirectly connects people from different cultures while taking place in the classroom, is collaborative story writing. Future language teachers might find it particularly useful as it focuses on pragmatic and semantic features of language, at the same time incorporating cultural elements, hidden values and beliefs from a particular culture. Therefore, learners work both on language and how culture is manifested through it.

In order to 'decipher' any critical incident, that is, a potential misunderstanding in intercultural communication, and make sense of behaviours and values at play, a number of tools can be used. Since in this project, the Serbian students were in charge of finishing the stories and resolving the conflicts in them, more attention will be given here to the possible theoretical frameworks they had at their disposal, which they acquired mostly through the Intercultural communicative competence course.

Firstly, culture models can be applied when the members of two cultures interact. Probably the oldest and most famous is E.T. Hall's model $(1956,1973)$ which includes dimension of collectivism and individualism and high- and low-context cultures. Others, more recent ones originated not from the educational but business setting, like Hofstede's (1997) and Trompenaars and Hampden-Turner's (1997). These models in many respects overlap with categories such as individualisms/ collectivism, time orientation, high and low power distance, ascribed and achieved status. Then, the 18-theme culture general framework might be applied (Brislin, 1993), organized into three categories: experience which engages people's emotions, knowledge areas, and bases of cultural differences. What these models have in common is that they try to explain a particular phenomenon from different perspectives and give an insight into different interpretations that members of different cultures might have on one and the same event. They also include the three basic domains of ICC - cognitive, affective and behavioural.

Then, the analysis of stereotypical images in order to explain intercultural misunderstanding might be another venue for students to become more interculturally competent. Stereotypes and prejudice theories do not only focus on the theories of social structure or ethnicities within one culture, but provide a framework for the analysis of racial politics and gender policies that might cause initial misunderstanding in intercultural relations. These theories are the ones that students usually most easily understand and most frequently use.

Another important tool is Bennett's Developmental Model of Intercultural Sensitivity (DMIS) (1993) that describes the different ways in which people react to cultural differences. However, at the point in the course when story writing took place, the students had not still encountered it, and these stories were used to explore the model and explain the stages of individual's sensitivity towards new experiences after the project was done. 


\subsection{Collaborative learning}

With a greater insistence on active learning, the introduction of flipped classrooms (Abeysekera \& Dawson, 2015), and more student-centred approaches to teaching, cooperative learning is becoming more of a norm than an isolated event in a language classroom, at all levels of education. Insisting on the active engagement in classes is especially important for future teachers, as their experiential learning can help later in their professional development by making the learning process more concrete. By exploring different projects and formats of teaching, pre-service teachers might be more willing to incorporate such models in their own teaching practice.

Projects of this kind provide students with loop input, "a specific type of experiential teacher training process that involves an alignment of the process and content of learning" (Woodward, 2003: 301).Being engaged in a project, going through all the phases provides future teachers with an insight into how their teaching practice can also be structured. Therefore, such projects can be used as an effective teacher training tool if they are accompanied by appropriate feedback sessions and decompression time (Woodward, 2003) where students would reflect on the goals and outcomes. Later on, they will be able to implement similar practices and engage their own learners in ICC learning.

One of the important benefits in collaborative learning is that "students' collaborative dialogues mediate the construction of linguistic knowledge and that this process of joint accomplishment of a task contributes to L2 learning (Swain, 1998, 2000, 2010; Swain et al., 2009)" Shehadeh (2011: 287). In addition, it has been noted that collaborative learning helps "students feel confident and helps them remember better, as well as generate more ideas" (Macaro, 1997: 135). In the context of higher education, students have an opportunity for a deeper exploration of a problem, where they will depend more on their peers that their instructor. Further, they will be able to see the learning process both from an inside, as a learner, and from an outside - during debriefing, as a future teacher.

In the context of collaborative learning, collaborative writing is one of the possible strategies to use. Collaborative writing can be defined as "1) substantive interaction in all stages of the writing process, 2) shared decision-making power over and responsibility for the text produced, and 3) the production of a single written document" (Storch, 2013: 2). Group writing has been a widespread practice in universities (Scotland, 2016) as it provides opportunities for teamwork and development of critical thinking skills (Shin, 2015). Ultimately, it can help with better individual writing and better task understanding and completion. In a collaborative story-writing project, there are many elements of cooperative learning (Kagan\&Kagan, 2009) where individual learners need to contribute to a common goal, developing the sense of responsibility and accountability for the project along the way.

The outcome of a collaborative activity or project is not only one, jointly produced text. It is "collective cognition, emerging when two or more people reach insights that neither could have reached alone, and that cannot be traced back to one's individual contribution" (Stahl, 2006 as cited in Storch, 2013: 3). This is even more obvious in intercultural writing projects, as the evidence of cooperation is concrete and is based on mutual work and joint reflection.

When the collaboration is between two groups of students who are from different cultures and who work on solving a problem, then the goals for the final product are not only in terms of the development of language competence. Here, the students engage in critical thinking, analysing the cultural elements that might be at play and only by joint effort can there be a resolution to the story they are creating. Both groups of students need to show more than just a 
cursory understanding of the target culture, a sound understanding of their own culture: in terms of objective elements and practices that stem from more deeply engrained beliefs and values.

\subsection{Story writing}

The Partnership Story Project started in 1989 within the actions taken up by Parents and Teachers forSocial Responsibility (PTSR) in Vermont in an attempt to bring together elementary school students from the US and a number of other countries - Mexico, Hungary, Norway, among others (Cushner, 1992). Learners need to explore the target culture of their interest, and then, as a group, write the beginning of a story illustrating a misunderstanding. They should develop characters, set the scene and bring it to a turning point where the characters would be required to (re)act - but not finish the story, so that the group of students in the target culture brings the story to its most logical conclusion. Stories should be designed so that they provide enough background information and set the scene for a misunderstanding that most often results from the lack of understanding of subjective cultures of the characters.

This is only the minimum for the project to start, depending on the proficiency and age of learners, the project can include drawings, audio recordings, photographs that would accompany the story. Once the stories are completed, both groups can use them for further learning, they can continue by rewriting segments, or discussing possible different resolutions.

In collaborative writing, upon reading the story, students firstly see only their culture's perspective as the 'right one'; naturally, people's assumptions about life stem from their own perspective, and when something clashes with it, people are distressed. The first responses to novel and unexpected situations are usually on an emotional level (Brislin, 1993), therefore, stories like these help learners better understand those emotions as they are discussed and explained and included in the story's 'resolution'. The strategies that have been most effective for improving intercultural understanding seem to be those where emotions are engaged through cognitive approaches (Cushner, 1992). Those strategies go beyond information transmission and engage students emotionally, developing their empathy and asking from them to analyse misunderstandings from different perspectives.

While students begin their learning process by allegedly writing stories, they will be involved in a serious contemplation on culture and critical analysis. They will be required to use and improve not only their linguistic skills but their intercultural sensitivity, intercultural knowledge, and collaborative skills and show their understanding of the workings of both their own and a target culture. Finally, the collaborative story writing project provides different venues for further cooperation and might engage students in online collaboration, work on different audio/ video material to supplement the story, etc.

\section{STUDY}

\subsection{Participants}

The story writing project connected two groups of students. The first one included 37 third-year students from the English language department at the Faculty of Philosophy, University of Nis who were taking the course in Intercultural communicative competence. The second was a group of 17 second-year education students from the School of Teaching, Learning and Curriculum Studies at the Kent State University in the program for Social 
studies in early childhood education, led by Professor Kenneth Cushner. The academic profiles of these two groups are not completely the same, in terms of the outcomes of their respective programs, but regarding their education in intercultural competence, they are trained toward similar goals: development of awareness, intercultural knowledge, competencies, and sensitivity.

\subsection{Procedure}

The American students were advised to research Serbia, its customs and culture and to devise the first half of the story. For that purpose, they got familiar with the most common Serbian names, food, some customs, holidays, and geographical features. The research they conducted was not structured in any other way, and the American students had to find resources on their own. The Serbian students had already taken different courses in the English speaking cultures (British and America studies, American literature, among others), had been in the Intercultural communicative competence course, and, as the English language majors, were well acquainted with the American culture.

As both groups of students are working towards their diplomas in teaching, the pivotal point of the story needed to be the classroom. The Serbian students received seven stories that they needed to finish while working in groups, over two classroom sessions.

\subsection{Methodology}

The stories were then analysed for the common topics and problems they raised. It was expected to see similar issues - the lack of language competence and not understanding the social mores in most of the stories. In order to analyse the contrasting elements that the students incorporated in the stories, Bennett's Developmental Model of Intercultural Sensitivity was used, as it provides room for instruction and guidance of individuals from ethnocentric to ethnorelative stages. It is based on "theoretical concepts to explain a pattern that emerges from systematic observations of behavior" (Bennett, 2004: 71), therefore, it was expected that students would focus on those situations in which the characters see "the world as organized into 'us and them', where one's own culture is superior and other cultures are inferior" (Bennett, 2004: 65). Another tool that was used to analyse the stories was the 18theme culture-general framework (Cushner \& Brislin, 1996), as it was expected that some of the themes in the three categories (experience which engage people's emotions; knowledge areas; bases of cultural differences) would be used by the American students to set up the stories, for example, anxiety, non-verbal communication, in-group vs. out-group, etc.

\subsection{Stories}

All the stories took place in elementary schools, with mostly Serbian students there as new-comers. Only one story took place in Serbia, with an American girl attending a Serbian school. The most immediate problems that the American students identified were the lack of linguistic competence and unfamiliarity with the local customs, which in turn, made individuals anxious and confronted with prejudice (Cushner \& Brislin, 1996).

The awareness of the key values and assumptions of one's own culture is a prerequisite for a solid and believable story. This is not an easy task for students, and requires not only factual knowledge but also a high level of cultural sensitivity. Students usually think that they know all there is to know about their own culture, but to understand the target culture, they need to understand "how it is different from their own" (Storti, 2009: 277). Only after they become 
aware of the beliefs and values in their culture can students better understand the target culture and identify the values, beliefs and behaviours that are different. The American students had to anticipate where their own culture might present obstacles to the understanding of newcomers.

In addition to the knowledge about one's own culture, it is important for students to know something about the target culture, so that they anticipate potential misunderstandings. Therefore, it was important for the American students to learn something about Serbia before they wrote the stories. Information they gathered helped them write more believable stories. Many stories, therefore, included the elements of ambiguity, when new-comers were not sure of how to navigate social contacts, and with the host culture individuals also at a loss as how to make the transition less traumatic. One story included superstition, though in a more stereotypical way, with a Serbian couple not disclosing the sex of the baby before its birth. Finally, almost all the stories stared by the American students included the in-group vs. out-group divide, as this is "one of the major basis for forming categories about people" (Cushner \& Brislin, 1996: 41).

The stories centred on the expected lack of linguistic and cultural knowledge in newcomers. For example, these problems are seen in the first quoted story, where the Serbian student did not know the rules of baseball, or in the second, where the Serbian students did not know how to start communicating, or how to properly greet new classmates, the students insisted on the surface, objective cultural elements. However, it has been shown that "the locals in a particular culture are typically quite forgiving of the faux pas or cultural mistakes that result from not knowing business and social etiquette" (Storti, 2009: 273) as well as prepared to give the benefit of the doubt to the newcomers. While bad impressions might hinder communication, they usually do not lead to the breakdown of communication. It is interesting that the students in both groups believed language competence to be the most important and focused on it as the cause of misunderstandings.

\subsubsection{Openings}

Here are the introductions to two stories:

1. Filip was a new student in Mr. Hatfield's $2^{\text {nd }}$ grade classroom in a small town in northeast Ohio. Filip had recently moved from Serbia. He is one of three children in his family. Filip's father can speak in conversational English because he is a businessman; he moved his family to America due to his job. Filip's mother speaks no English, and since the move, she stays at home.

On the playground, Filip typically keeps to himself. He did not play much with other children, so Mr. Hatfield suggested to some of the more outgoing students in his classroom that they should include Filip in their recess activities. Once they began to include him in their activities, conflicts arose. The children were playing baseball on the playground; it was Filip's turn to bat. He stood at home plate, and the pitcher pitched the ball. Filip hit the ball on the outfield and then began running from the plate to the pitcher's mould.

"HEY, WHAT ARE YOU DOING!? THAT'S NOT HOW YOU PLAY!" yelled Tommy from across the field.

Filip stopped what he was doing and stared back at Tommy, unsure what to do or say. As Tommy approached to speak with Filip, Mr. Hatfield blew the whistle, signaling that it was time for the children to line up and go back inside.

Later in the day, Mr. Hatfield overheard Tommy talking with some friends about how Filip had 'ruined their game'.

"What was going on at recess, Tommy?" asked Mr. Hatfield.

Tommy explained what had happened, and Mr. Hatfield knew he would have to intervene. 
2. One day, the $3^{\text {rd }}$ grade got a new student named Stefana. She just moved into her new home in the States from Serbia. Her English was minimal and she was just beginning to learn the language. She is able to say a few greetings but she couldn't form complete sentences in English yet.

When Stefana arrived in the classroom, the students weren't sure how to interact with the new student. The students didn't understand her customs or how to properly greet her. When the teacher introduced Stefana, one child yelled out 'Why doesn't she talk like we do?". The teacher explained that she was from a different country, but the children were still confused. They were worried about offending her with their gestures or greetings.

Throughout the day, Stefana was ignored by her classmates. The children didn't' know how to include her into their daily activities. She felt unwelcome in the classroom. The teacher was having a difficult time making Stefana a part of their classroom community. She decided that she needed advice from another teacher who had more experience with ESL learners.

What we can see in the openings to the stories are the elements of different ethnorelative stages. For example, in both cited stories the young American students complained that the newcomers did not know how to adapt to the existing rules - either of baseball or language. Therefore, the characters express features of the Defense stage (Bennett, 2004), where they want to bring the 'non-dominant' group "into the assumedly superior dominant culture" (Bennett 2004: 65). The participants rightly recognized that individuals without much experience with intercultural encounters might be more reluctant to and critical of a different culture. The polarized worldview is another characteristic of an ethnorelative perspective; the divisions into 'us' as opposed to 'them' is not uncommon, and the students showed it in their stories: in stating 'that's not how you play' or 'why doesn't she talk like we do?'.

Both groups of students probably decided to include objective culture elements because these are the ones instantly visible, this information is readily available in guides and textbooks and from this basis further exploration of culture usually starts. While this might not seem as an important insight, some studies (Keller 1991, Coleman 1998) have shown that entering intercultural encounters believing that linguistic competence will be enough is the safest way to end up with misunderstanding and failed expectations. On the other hand, the more competent a speaker is in a language, the better the hearer expects their cultural competence to be, if linguistic competence is not followed by cultural competence the speaker will 'not be excused easily'. Therefore, it can be said that the students showed the awareness of the importance of language for intercultural communication. However, while novice in culture and novice in language might go together and be expected, stories go against the findings that language learning has little impact on intercultural sensitivity (Bhawuk \& Brislin, 1992).

Finally, the stories turned out to be very telling of the usual first impressions and stereotypes. For example, in all the stories that took place in the States, where the reason for the move was stated, it was the fathers who changed jobs, while mothers stayed at home. Another one was that the newcomers would be unfriendly, shy, and not forthcoming, as many stories played on these features of the main characters. The stereotypical behaviours might be explained with the expected 'out-group' behaviour. There are different "ways of constructing the cultural Other: the cultures to which you belong tell you how those in different cultures [...] are to be read and understood" (Holliday et al., 2004:180). Without much information and no personal experience to go on, such dichotomies and stereotypes might be expected, as "direct contact often strengthens the pre-existing associations between the target group and the stereotypical properties” (Hercht et al., 2003: 62 as cited in Samovar et al., 2010: 172). 


\subsubsection{Endings}

When the Serbian students wrote the endings to the stories, they did it based on the material covered in the ICC course, with five to six students per group. All the stories were supposed to have a successful resolution that would logically follow from the cultural values and mores.

Here are the endings to the two stories:

1. Mr. Hatfield called Filip and Tommy after classes to his office, so as to hear both sides of the story and try to resolve the conflict. Tommy said that Filip did not follow the rules, ruining the game for everyone - which made him very angry.

Mr. Hatfield then asked Filip why he had not asked anyone to explain the rules to him. Fillip said that he was anxious and felt like an alien, because nobody wanted talk to him. His first attempt to fit was a failure which caused fear, preventing him from trying it again. He thought they had a lot of prejudices because he was from a country they had not even heard about.

Tommy said: "And that's exactly why I approached him - I wanted to explain the rules".

To what Mr. Hatfield replied: "OK, I thought you might attack him, so I intervened. I, obviously, misinterpreted your intentions. Now, you two, it has to be clear that there are many intercultural schools, there is a great diversity of people with different backgrounds coming to them. We have to take culture into consideration. Because, culture, is a secret. Pretty much, we know that we don't know. To know more, we need to talk, to interact with people. We should show willingness and interest in other cultures, we should avoid judging people and we should understand them. If we don't do that, the problems will remain. It's not an easy task, it takes effort and time, but the result is great"

The boys agree and shake hands.

2. Surprisingly, she learned that the wife of her colleague was Serbian. She contacted her and asked for help in acclimatizing Stefana to the new environment. The woman, Mrs Milica Cartman, agreed to talk to Stefana one-on-one and introduce her to American culture, as well as giving a few English lessons to speed up the whole process. Stefana was stoked to meet someone outside of her family she could communicate with and was soon able to break the ice with her classmates and start to fit in. She in turn introduced them to some aspects of her own culture, such as Serbian greetings and ethno music, and was gradually accepted. Since her classmates heard a bit of the Serbian language, they no longer thought her so strange because of the way she spoke. They even started kissing each other on the cheek as a greeting.

The endings provided by the Serbian students included more explanations about the actions than the actions themselves. This was seen as a natural step in the procedure that was new to them, so rather than paying attention to how the story might develop, the students probably found it easier to discuss the reasons behind and workings of a culture. The students focused on the 'lecturing' and a message of the stories, stressing the importance of a nonjudgemental approach. Also, the students wanted to show a bit more intimate knowledge of the American popular culture, and even included such a reference in the story - referring to South Park character's name, Cartman.

The Serbian students did not rely on the cultural models they knew (Hall, Hofstede, Trompenaars and Hampden-Turner), and relied more on general cultural elements. This was expected, since the issues in the stories did not follow from cultural dimension such as time orientation, high or low uncertainty avoidance, and the like. They followed in the themes set up by the American students, and as solutions to breakdowns in communication offered additional language instruction for new comers, organizing parties: both by the hosts and the newcomers, and presenting food as a universal bridge to other cultures. 
The students invoked the common humanity of people of other cultures as the most frequent manner of resolution of misunderstandings in stories. This might seem as a commonsense solution, but, it is also the one recognized by Bennett (2004) as leading individuals from the stage of Defense into more ethnorelative stages. Bennett believes that correcting the stereotypes or offering complex explanations does not lead to understanding but to further polarization. He, therefore, suggests, as the students themselves did, establishing commonality that will later lead to a deeper understanding of cultures.

The ending for the first story is a textbook example of the way individuals in the Minimization stage deal with ICC misunderstandings. The teacher in the story calls for the "acceptance of something like the 'melting pot' idea [...] the experience is [...] minimizes the cultural differences between the dominant and non-dominant groups in such a way that the same universal standard can be applied to all the groups without bias" (Bennett, 2004: 68). This reaction proved that students themselves were not completely interculturally aware and competent - which they were not expected to be half-way through the course. This worldview - "all people are essentially similar in ways that explainable by my own cultural beliefs" (Bennett, 2004: 70) - is probably the most difficult to change, as individuals think they are acknowledging the differences. This is where students need to become aware of the context of a particular culture, and where the follow-up discussion might bring a deeper insight into the cultural elements.

The fact that the Serbian students focused more on the teaching aspect of the stories, that is, providing more of the analysis than story line might be explained by their in-service teacher-training. Since the ICC course they were attending was organised with the view of strengthening the intercultural component in language teaching, the 'lecturing' in story writing might be seen a positive outcome. In addition, this was where they as students underwent the whole process of collaborative writing; while learning themselves about the process and putting into practice their knowledge, the students were also going through the "loop input" (Woodward, 2003). Hopefully, the students would be more prone to consider using these types of techniques in their own classrooms, as they went through this type of experiential learning.

\section{CONCLUSION}

The fact that both groups of students stereotyped the characters from the target cultures points to several things. Firstly, the first impressions will invariably be based on the pre-taught categories, be they from the media, upbringing or some other source. The surface and objective elements of culture are the easiest to see, and therefore will be used to guide one's behaviour, although the mismatch between the visible and hidden elements in two different cultures would more often than not lead to a misunderstanding.

The students recognized Defense and Denial stages (Bennett, 2004) as the first reactions people might have in initial encounters between cultures. Even though the Serbian students had different models at their disposal to use when analysing the stories, the initial set up given by their American counterparts provided the framework within which to work. The Serbian students, therefore, mostly used stereotype theory and, inadvertently, Bennett's model.

Both groups of students, but especially the Serbian ones put a heavy focus on the idea that 'we are all human', together with a thorough explanations why people need to get along. While this shows that students themselves were not completely in the ethnorelative 
stages, it is a promising start for the further development of all three ICC domains. The projects of this type might help students see that beliefs, behaviours, and values are influenced by the particular context in which they were socialized (Bennett, 2004) and consequently imagine alternatives to them.

The collaborative writing turned out to be a very useful tool for culture analysis in several respects. Firstly, the Serbian students have received almost exclusively "monocultural socialization [and] normally have access only to their own cultural worldview", so they might find it difficult to "experience the difference between their own perception and that of people who are culturally different" (Bennett 2004: 74). The story writing engages students, especially because they are interacting with the members of the target culture. Secondly, the instruction that provides students with more immediate experience of a different culture enables them to more critically and objectively observe their culture and raise their selfawareness. Then, preparing cultural episodes for students as a means of intercultural communication instruction can easily be coupled with student-made material. In terms of student engagement, active learning and putting into practice what they study, story writing, and especially, collaborative story writing can be a worthwhile activity. Finally, when students are led through activities like this, they easily get 'loop input' (Woodward, 2003) and might be more likely to incorporate similar activities in their own teaching practice. Therefore, collaborative story writing could be beneficial not only for their personal, but also for their professional development.

Acknowledgement: The author wishes to thank the American Embassy for their long lasting support and especially for the English Language Specialist grant through which Professor Cushner was able to give lectures and organize workshops with students at the English language department in 2011 and 2014.

\section{REFERENCES}

Abeysekera, L., P. Dawson (2015), "Motivation and cognitive load in the flipped classroom: definition, rationale and a call for research", Higher Education Research \& Development, 34:1, 1-14, DOI:10.1080/07294360.2014.934336.

Bennett, M.J. (1993), Towardsethnorelativism: A developmental model of intercultural sensitivity. In R.M. Paige (Ed.), Education for the intercultural experience ( $2^{\text {nd }}$ ed.). Yarmouth, ME: Intercultural Press. pp. 21-71.

Bennett, M. J. (2004), Becoming interculturally competent. In J.S. Wurzel (Ed.) Toward multiculturalism: A reader in multicultural education. Newton, MA: Intercultural Resource Corporation. pp. 62-77.

Bhawuk, D. P. S., Brislin, R. (1992), "The measurement of intercultural sensitivity using the concepts of individualism and collectivism", International Journal of Intercultural Relations, 16, pp: 413-36.

Brislin, R.W. (1993), Understanding culture's influence on behavior. Forth Worth, TX: Harcourt Brace Jovanovich.

Byram, M. \&Risager, K. (1999), Language Teachers, Politics and Cultures. Clevedon: Multilingual Matters.

Byram, M. (2009), Intercultural Competence in Foreign Languages - The Intercultural Speaker and the Pedagogy of Foreign Language Education. In Deardorff, D.K. (ed.) The Sage Handbook of Intercultural Competence. Thousand Oaks, CA: Sage. pp: 321-332.

Coleman, J. (1998). Evolving intercultural perceptions among university language learners in Europe. In Byram, M. and M. Fleming (Eds.), Language learning in intercultural perspective. Cambridge: CUP.pp: 45-75.

Council of Europe (2001), Common European framework of reference for languages: learning, teaching, assessment. Cambridge: CUP.

Cushner, K. (1992), "Creating Cross-Cultural Understanding through Internationally Cooperative Story Writing", Social Education, 56(1): pp. 43-46.

Cushner, K. (2011), "Intercultural Research in Teacher Education: An Essential Intersection in the Preparation of Globally Competent Teachers", Action in Teacher Education, 33:5-6, pp: 601-614.

Cushner, K., R. W. Brislin (1996), Intercultural Interactions. A Practical Guide. Thousand Oaks: Sage Publications. 
Curriculum for elementary and high school education. Retrieved from http://www.zuov.gov.rs/poslovi/nastavniplanovi/nastavni-planovi-os-i-ss/

Deardorff, D. K. (2012), Introduce Core Concepts. In K. Berardo\& D. K. Deardorff (Eds.) Building Cultural Competence: Innovative Activities and Models. Sterling, Virginia: Stylus. pp: 45-52.

Gutiérrez, K. (2000), "Teaching and Learning in the $21^{\text {st }}$ Century", English Education Vol.32, No. 4. pp: $290-298$.

Hall,E. T. (1973), Silent Language. New York: Anchor Books.

Hammer, M. R., M. J. Bennett, R. Wiseman (2003), "Measuring intercultural sensitivity: The intercultural development inventory", International Journal of Intercultural Relations, 27: 421-443. doi:10.1016/S01471767(03)00032-4.

Hofstede, G. (1997), Cultures and Organizations: Software of the Mind. New York: McGraw-Hill.

Holliday, A., M. Hyde, J. Kullman (2004), Intercultural Communication. An Advanced Resource Book. London, New York: Routledge.

Kagan, S., M. Kagan (2009), Cooperative Learning. San Clemente, CA: KCL: BKCL.

Keller, G. (1991), Stereotypes in intercultural communication: effects of German-British pupil exchanges. In D. Buttjes and M. Byram (Eds.), Mediating languages and cultures. Clevedon: Multilingual Matters. pp: 103-119.

Kramsch, C. (1993, $2^{\text {nd }}$ ed. 2003). Context and culture in language teaching. Oxford: OUP

Macaro, E. (1997), Target Language, Collaborative Learning and Autonomy Clevedon: Multilingual matters.

Samovar, L.A., R.E. Porter, E.R. McDaniel (2010), Communication Between Cultures ( $7^{\text {th }}$ ed.). Boston: Wadsworth

Scotland, J. (2016), "How the experience of assessed collaborative writing impacts on undergraduate students' perceptions of assessed group work", Assessment \& Evaluation in Higher Education, 41(1), 15-34.

Shehadeh, A. (2011), "Effects and student perceptions of collaborative writing in L2". Journal of Second Language Writing, 20(4), 286-305.

Shin, M. (2015), "Collaborative learning”, English Teaching Professional, 97, 11-13.

Storch, N. (2013), Collaborative writing in L2 classroom. Bristol: Multilingual matters.

Triandis, H. C. (2002), "Subjective Culture", Online Readings in Psychology and Culture, 2(2). Retrieved from http://dx.doi.org/10.9707/2307-0919.1021.

Trilling, B., C. Fadel (2009), $21^{\text {st }}$ Century Skills: Learning for Life in Our Times. San Francisco: John Wiley \& Sons.

Trompenaars, F, C. Hampden-Turner (1997), Riding the Waves of Culture: Understanding Culture Diversity in Business. London:Nicholas Brealey Publishing.

Woodward, T. (2003), "Loop input", ELT Journal, 57(3), 301-304.

\section{ZAJEDNIČKO PISANJE PRIČA KAO NAČIN RAZVIJANJA INTERKULTURNE KOMUNIKATIVNE KOMPETENCIJE}

Rad na razvijanju interkulturne komunikativne kompetencije $u$ okvirima učionice suočava se sa mnogo prepreka: ne samo formalnih, u smislu izbora pristupa, materijala i ocenjivanja, već $i$ etičkih $i$ vrednosnih. Razvijanje interkulturne svesti kod budućih nastavnika je jednako važno, jer oni treba da budu spremni ne samo za interkulturnu učionicu već i za raznolikost koja je prisutna u svakoj učionici: etnička, socijalno-ekonomska, polna, pa i raznolikost u stilovima učenja. Jedna od mnogih tehnika koje se koriste u interkulturnim učionicama je kolaborativno pisanje priča. Američki i srpski studenti uradili su zajednički projekat tako što su ovi prvi napisali početke, uz pomoć profesora Keneta Kušnera, eksperta u polju interkulturne komunikacije, a ovi drugi krajeve priča. Ove zajedničke priče pokazale su da obe grupe studenata imaju delimično stereotipne stavove prema drugoj kulturi, ali i da su svesni koraka koje treba preuzeti kako bi se interkulturna komunikacija popravila. Sprovedeno istraživanje će poslužiti da pokaže kako se može uticati na razvijanje razumevanja kulture, sa naglaskom na to kako budući nastavnici engleskog jezika mogu da iskoriste iskustvo za svoj nastavni rad.

Ključne reči: interkulturna komopetencija, obrazovanje nastavnika engleskog jezika, kolaborativno pisanje priča, projekti, strategije razvijanja svesti 